\title{
Improved Survival in Patients with Multiple Myeloma Treated with DMVM plus IFN- $\alpha$
}

\author{
Teruo Kitani, Yukihiro Tokumine, Tohru Masaoka, Atsushi Horiuchi, Eizo Kakishita, \\ Takashi Kageyama, Noriyuki Tatsumi, Jun Kuyama, Kunio Hayashi, Machiko Tsukaguchi, \\ Hiroya Kawagoe, Hedeki Fujitake, Tadahiro Tsubakio, Kaori Nasu, Yoshiteru Konaka, \\ Tsuyoshi Yonezawa and Kiyoyasu Nagai. \\ for the Hanshin Study Group on Treatment for Hematological Disorders
}

We examined effects of combination chemotherapy with dexamethasone, melphalan, vincristine, and MCNU (DMVM), plus IFN- $\alpha$ in patients with previously untreated and treated multiple myeloma (MM). In the study, 78 previously untreated and 47 treated MM patients were evaluated. The overall response rate was 76\% [27\% complete response (CR)] : 85\% [37\% CR] in previously untreated patients and $62 \%[11 \% \mathrm{CR}]$ in previously treated patients. The $50 \%$ survival time was 45.3 months for untreated patients and 30.1 months for previously treated patients. This regimen is effective in producing a high CR rate and prolonging survival duration of MM patients.

Key words DMVM+IFN- $\alpha$, multiple myeloma

\section{INTRODUCTION}

Facilitated by therapeutic improvement in high-dose therapy followed by peripheral blood stem cell transplantation (PBSCT) for leukemias and lymphomas, PBSCT has been introduced in the therapy of for multiple myeloma (MM). In addition, since interferon (IFN)- $\alpha$ is known to be effective in MM, modified combination chemotherapy with IFN- $\alpha$ has been performed. Thus, treatment for MM includes chemotherapy, INF- $\alpha$, radiation, bone marrow transplantation, and PBSCT ${ }^{1}$. The progress in therapeutic outcome with these approaches has revealed that some proportion of MM patients may attain CR.

We developed a DMVM + IFN- $\alpha$ regimen that combines dexamethasone, melphalan, vincristine, and MCNU with IFN$\alpha$ therapy. In a preliminary study, response rates for total 18 patients ( 8 untreated patients, 10 treated patients) showed were $69 \%$ and $38 \%$ for $\mathrm{CR}+\mathrm{PR}$ and $\mathrm{CR}$, respectively ${ }^{2}$. The high response rate prompted us to perform this multicenter study in patients with previously untreated and treated MM.

\section{Received: Dec 7, 2004}

Revised : Jul 1, 2005

Accepted: Jul 1, 2005

Sakai Municipal Hospital, 1- 1 Minamiyasui-cho, Sakai City, 590- 0064, Osaka, Japan Address correspondence and reprint request to Teruo Kitani, Sakai Municipal Hospital,

1-1 Minamiyasui-cho, Sakai City, 590-0064, Osaka, Japan

\section{MATERIALS AND METHODS}

\section{Patient selection and accrual}

Eligibility required a diagnosis of MM confirmed by bone marrow plasmacytosis of at least $10 \%$ as well as documented M-protein in either serum or urine or characteristic osteolytic bone lesions. Measurable disease implied a serum M-protein level of greater than $3 \mathrm{~g} / \mathrm{dl}$, or urine monoclonal light chain excretion greater than $1 \mathrm{~g} / 24 \mathrm{hr}$.

Staging was performed in accordance with to DurieSalmon's criteria, in which patients with creatinine level less than $2 \mathrm{mg} / \mathrm{dl}$ are subclassified as A, and those with creatinine level not less than $2 \mathrm{mg} / \mathrm{dl}$ are subclassified as B. In our study, patients with creatinine level between 1.2 and 2 were commented as "stage A with mild renal dysfunction."

\section{Study design}

The DMVM+IFN- $\alpha$ therapy regimen was administered as follows: dexamethasone $40 \mathrm{mg} /$ patient by drip infusion (d.i.) or orally (p.o.) on days 1-4, 9-12, and 17-20 ; melphalan $12 \mathrm{mg} /$ patient p.o. on days $1-6$; vincristine $1.2 \mathrm{mg} / \mathrm{m}^{2}$ (max $2 \mathrm{mg}$ ) intravenously (i.v.) on day 1; MCNU $70 \mathrm{mg} / \mathrm{pa}-$ tient i.v. on day 1 ; and IFN- $\alpha 3 \times 10^{6} \mathrm{IU} /$ patient was administered intramuscularly on days $1-20$. In cases that exhi- 
bited myelosuppression on day 12 , IFN- $\alpha$ was sometimes withheld on investigator preference. The DMVM+IFN- $\alpha$ regimen was repeated two or three times every 6 or 8 weeks.

\section{Dose modification}

Chemotherapy was administered at full dose, except for patients aged 70 years or older, who began treatment with a $25 \%$ reduction in MCNU dosage. In patients with renal dysfunction, dosages were reduced on investigator preference.

\section{Response criteria}

Criteria for remission were as follows : complete remission (CR) referred to disappearance of M-protein or BenceJones protein, decrease to less than $5 \%$ of bone marrow plasma cells, and alleviation of symptoms due to MM (lumbago, bone pain, fatigue and palpitation); partial remission (PR) referred to a greater than $50 \%$ decrease in M-protein or Bence-Jones protein ; minor response (MR) was defined as a decrease between 25 and $50 \%$; no change (NC) was defined as less than $25 \%$ decrease. These responses must have persisted for at least 4 weeks.

Progressive disease referred to greater than $25 \%$ increase in M-protein or Bence-Jones protein. Progression of disease was defined as an increase of M-protein or Bence-Jones excretion by $50 \%$ above the previous nadir obtained during the best response to treatment. Response duration was determined as the time from attainment of response to the date of progression.

\section{Statical method}

Two-tailed Fisher's exact test was used to compare CR rates between two groups. Survival distribution was estimated with Kaplan-Meier curves and compared by Log-Rank test.

Logistic regression analyses were performed to determine which variables were related to the effects $(\mathrm{CR}+\mathrm{PR})$.
$\mathrm{P}$ value less than 0.05 (2-tailed) was considered to indicate significance.

All analyses were performed with the use of SAS software (version 8.02, SAS Institute).

\section{RESULTS}

From 1989 to 1996 , of 140 patients registered, 10 patients who did not fulfill the eligibility criteria were excluded from evaluation, and 5 patients were not evaluated because of early withdrawal from the assigned treatment due to the following adverse effects; myelosuppression in 2 cases, and interstitial pneumonia, psychiatric reaction, and ventricular tachycardia in one case each. The remaining 125 patients were eligible. These included 78 previously untreated and 47 treated MM patients. All patients gave informed consent before being entered into the study. The patient characteristics are shown in Table 1.

The 50\% duration of follow-up (from first DMVM+IFN$\alpha$ administration to death, or to a $50 \%$ date last seen in the surviving patients) was 45.3 months for untreated patients and 30.1 months for previously treated patients.

\section{Response}

The response to therapy is summarized in Table 2. Of the previously untreated patients, 29 (37\%) achieved CR and 37 (47\%) achieved PR. Of the previously treated patients, 5 (11\%) achieved CR and $24(51 \%)$ PR. The difference in the $\mathrm{CR}$ rates between the two patient groups was significant (Chisquare $P=0.005$ ). The $50 \%$ response duration was 16.2 , 19.7, and 12.7 months for untreated patients with CR+PR, $\mathrm{CR}$, and PR, respectively. The $50 \%$ response duration was $10.1,18.5$, and 7.6 months for previously treated patients with $\mathrm{CR}+\mathrm{PR}, \mathrm{CR}$, and PR, respectively.

\section{Survival}

The $50 \%$ survival time from the start of DMVM+IFN- $\alpha$

Table 1. Characteristics of patients

\begin{tabular}{|c|c|c|c|c|}
\hline Number of patients & \multicolumn{4}{|c|}{125 (Number of eligible subjects) } \\
\hline Age & \multicolumn{4}{|c|}{ 31-84 years (Median 61) } \\
\hline Sex & \multicolumn{4}{|c|}{54 males, 71 females } \\
\hline \multirow[t]{2}{*}{ Stage } & IA : 10 patients & IIA : 28 patients $^{*}$ & IIIA : 73 patients $\S$ & \\
\hline & IB : 0 patients & IIB : 2 patients & IIIB : 12 patients & \\
\hline \multirow[t]{2}{*}{ Disease type } & $\operatorname{IgG} \varkappa$ : 49 patients & $\operatorname{Ig} A \varkappa: 10$ patients & $\operatorname{IgD} \varkappa: 0$ patients & $\mathrm{BJP} \varkappa: 7$ patients \\
\hline & $\operatorname{IgG} \lambda$ : 33 patients & $\operatorname{IgA} \lambda: 13$ patients & $\operatorname{IgD} \lambda: 4$ patients & $\mathrm{BJP} \lambda$ : 9 patients \\
\hline Previous treatments & No 78 , & Yes 47 & & \\
\hline
\end{tabular}

* Stage II with mild renal dysfunction : 2 patients

$\S$ Stage III with mild renal dysfunction : 6 patients 
Table 2. Clinical effects and stage of disease

\begin{tabular}{lrrrrrrr}
\hline \multirow{2}{*}{ Treatment/ Stage } & \multicolumn{3}{c}{ Number of patients } & \multicolumn{3}{c}{ Response rate (\%) } \\
\cline { 2 - 8 } & & CR & PR & MR & CR & CR+PR & CR+PR+MR \\
\hline Total number of patients & 125 & 34 & 61 & 25 & 27 & 76 & 96 \\
$\quad$ Stage I & 7 & 5 & 1 & 1 & 71 & 86 & 100 \\
Stage II & 18 & 6 & 10 & 1 & 33 & 89 & 94 \\
Stage III & 53 & 18 & 26 & 8 & 34 & 83 & 98 \\
Previously untreated & 78 & 29 & 37 & 10 & 37 & 85 & 97 \\
$\quad$ Stage I & 3 & 1 & 1 & 1 & 33 & 67 & 100 \\
$\quad$ Stage II & 12 & 1 & 9 & 2 & 8 & 83 & 100 \\
$\quad$ Stage III & 32 & 3 & 14 & 12 & 9 & 53 & 91 \\
Previously treated & 47 & 5 & 24 & 15 & 11 & 62 & 94 \\
\hline
\end{tabular}

was 45.3 months for previously untreated patients and 30.1 months for previously treated patients (Fig. 1). For untreated patients, the $50 \%$ survival duration was 53.2 and 39.0 months for patients with $\mathrm{CR}$ and PR respectively (Fig. 2).

\section{Response according to Ig isotype}

Response in terms of Ig isotype was analyzed for all 125 patients. The CR rate increased to in the order of $\operatorname{IgG}(20 \%)$, IgA (26\%), $\operatorname{IgD}(50 \%)$, and BJP (63\%) (Table 3). The 50\% duration of response (CR+PR) was 17.7, 17.5, and 10.6 months for patients with BJP, IgG, and IgA myeloma, respectively. The 50\% survival time was 43.1, 47.8, and 24.6 months for patients with BJP, IgG, and IgA, respectively (Fig. $3)$.

\section{Factors affecting response and survival}

Factors affecting response $(\mathrm{CR}+\mathrm{PR})$ are shown in Table 4. For all patients, including previously treated patients, hemoglobin and platelets were associated with response.

With respect to Ig isotype, subdivision of patients into untreated and previously treated patients resulted in populations too small to investigate statistically.

\section{Dose modification and response in patients with renal dysfunction}

In patients with renal dysfunction, dosages were reduced on investigator preference. Table 5 shows the dose modification and creatinine levels during the first course of DMVM+IFN- $\alpha$ and the clinical effects in patients with stage $\mathrm{B}$ and mild renal dysfunction. In most cases, the creatinine level improved during the first course of therapy.

In some several cases, IFN- $\alpha$ was not administered : due owing to refusal in 2 cases, and discontinued due owing to adverse effects in 3 cases. In these cases, DMVM alone also showed antitumor effects.

\section{Toxicity}

Side effects derived from characteristics of IFN- $\alpha$ were distinguished, especially subclinical fever and fatigue. These effects ameliorated gradually over time (Table 6). Myelosuppression, mainly due to DMVM regimen, was usually not severe. Thrombocytopenia requiring platelet transfusion was observed in 3 cases. Neutropenia below $1,000 / \mu \mathrm{L}$ was also observed, in 6 cases.

\section{DISCUSSION}

The authors devised a novel chemotherapeutic regimen for MM involving use of anticancer drugs shown to be beneficial in previous regimens combined with high-dose steroid hormone. This regimen includes melphalan, vincristine, MCNU, and dexamethasone. Melphalan and vincristine, a nitrosourea, were selected as alkylating agents. MCNU was substituted for BCNU, which is not commercially available in Japan. Dexamethasone was administered in the same manner as VAD therapy ${ }^{3,4}$. Alexanian, et al. reported that in VAD therapy, which is known as an efficacious regimen, dexamethasone was most effective $e^{5}$. Vincristine was administered by bolus injection to facilitate administration procedures. Doxorubicin, which was not so effective in our previous regimen, was excluded from the present regimen.

IFN- $\alpha$ was first used as monotherapy in remission induction therapy and then in combination with chemotherapy. The combination regimen is subdivided into two types : concurrent use of IFN- $\alpha$ and chemotherapy, and alternating use. As Cooper, et al. have reported an additive action between 


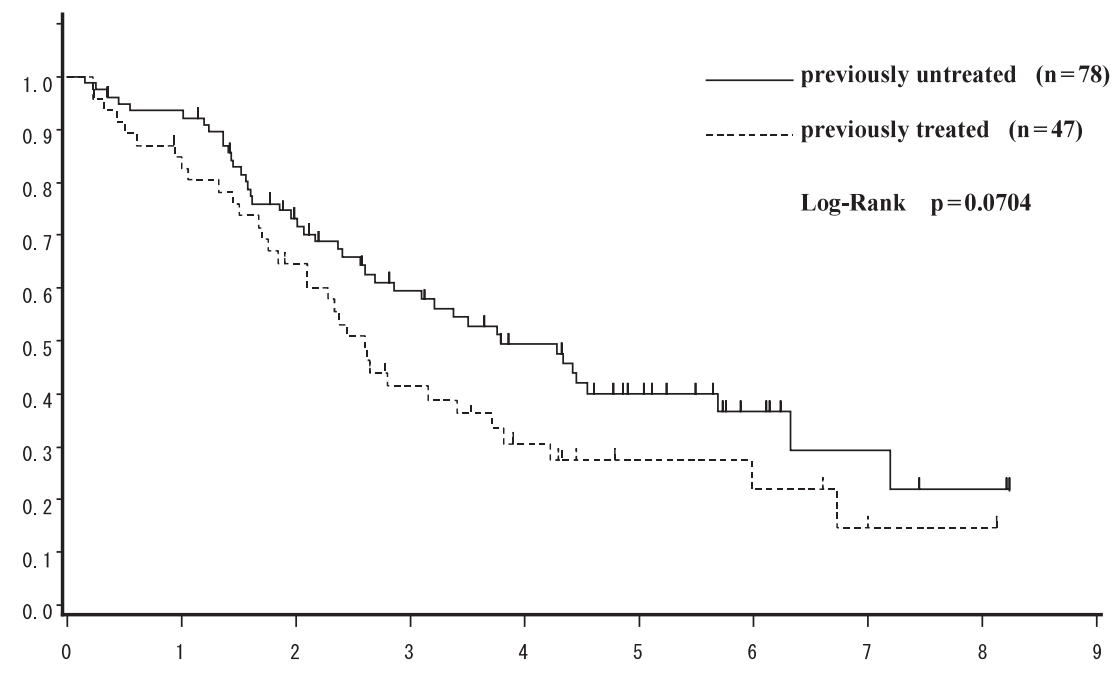

Fig. 1. Survival period of patients with and without previous treatments, from the beginning of induction therapy

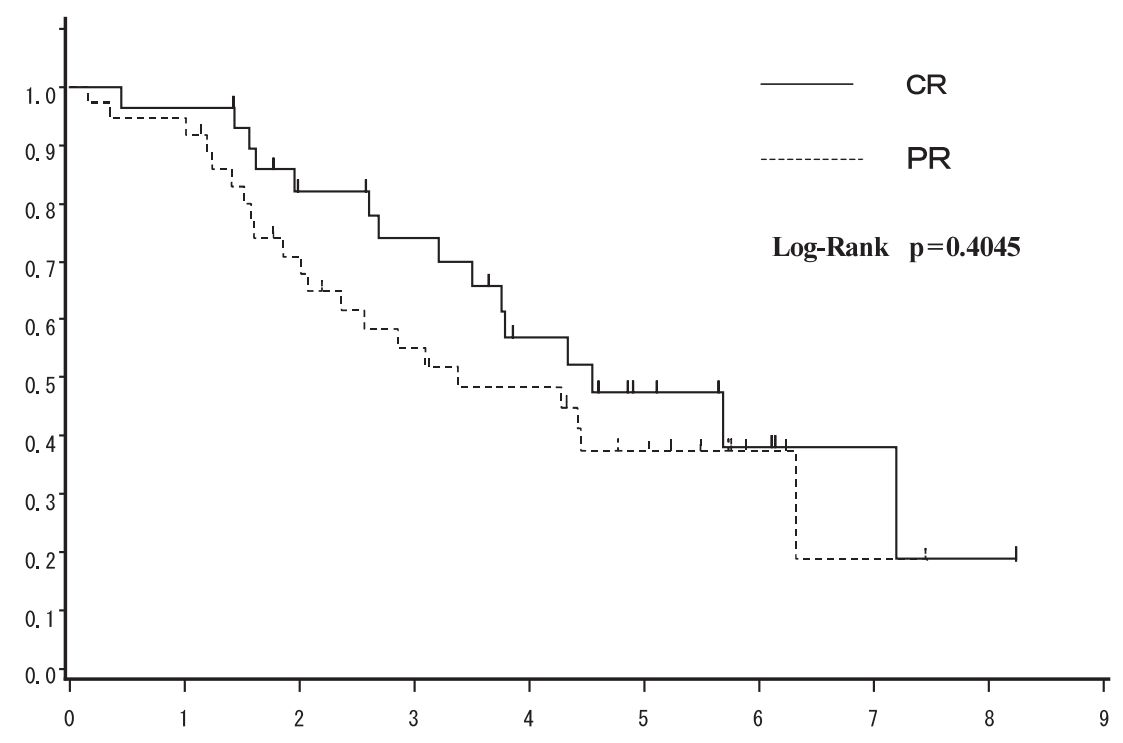

Fig. 2. Survival of previously untreated patients, according to clinical response

Table 3. Clinical effects according to Ig isotype

\begin{tabular}{lrrrrrrc}
\hline \multirow{2}{*}{ Therapeutic effects } & \multicolumn{4}{c}{ Number of Patients } & \multicolumn{2}{c}{ Response rate (\%) } \\
\cline { 2 - 8 } & & CR & PR & MR & NC/PD & CR & CR+PR \\
\hline IgG & 82 & 16 & 42 & 21 & 3 & 20 & 71 \\
IgA & 23 & 6 & 12 & 4 & 1 & 26 & 78 \\
IgD & 4 & 2 & 2 & & & 50 & 100 \\
BJP & 16 & 10 & 5 & & 1 & 63 & 94 \\
All patients & 125 & 34 & 61 & 25 & 5 & 27 & 76 \\
\hline
\end{tabular}




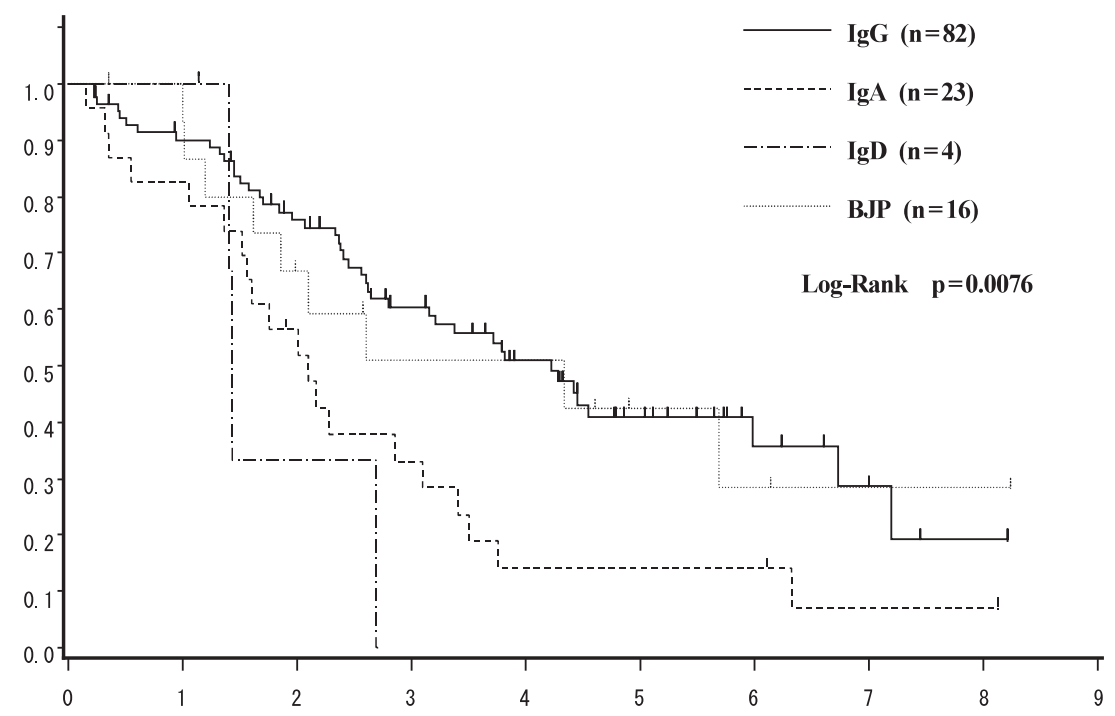

Fig 3. Survival curves according to the Ig isotype

Table 4. Prognostic factors in DMVM+IFN- $a$ therapy

\begin{tabular}{llccc}
\hline \multirow{2}{*}{ Treatment } & \multicolumn{3}{c}{ Factors related to effects $(\mathrm{CR}+\mathrm{PR})^{*}$} \\
\cline { 2 - 5 } & \multicolumn{1}{c}{$\begin{array}{l}\text { Univariate logistic regres- } \\
\text { sion analysis\# }\end{array}$} & $\begin{array}{l}\text { Multivariate logistic re- } \\
\text { gression analysis\# }\end{array}$ \\
\hline $\begin{array}{l}\text { Previously untreated } \\
\text { Previously treated }\end{array}$ & Hemoglobin & 0.023 & \multicolumn{2}{c}{ N.S. } \\
All patients & Hemoglobin & 0.023 & Hemoglobin & 0.024 \\
& Platelets & 0.009 & & \\
\hline
\end{tabular}

\# $\mathrm{P}$ value.

IFN- $\alpha$ and chemotherapeutic drugs in vitro ${ }^{6}$, the former regimen was selected.

The present study demonstrated that DMVM+IFN- $\alpha$ therapy is an effective regimen achieving a high rate of response, including CR. There have been many reports of the therapeutic results of MP therapy, a standard chemotherapy for $\mathrm{MM}$, since the report by Alexanian, et $a l^{7}$. Gregory reported, in summary, that the remission rate (PR or higher) was around $60 \%$ with $\mathrm{CR}$ rarely noted, and the average survival time was approx. 32 months $^{8}$. In contrast, the present DMVM+IFN- $\alpha$ therapy produced a response rate of $76 \%$ including a CR rate of $27 \%$, and a $50 \%$ survival time of 38.1 months. The remission effect was particularly high in untreated patients, with a response rate of $85 \%$ including a CR rate of $37 \%$, while even in previously treated patients (mostly with MP therapy), the response rate was $62 \%$ including the CR rate of $11 \%$. Furthermore, responders $(\mathrm{CR}+\mathrm{PR})$ showed improvement in quality of life (QOL) in association with alleviation of pain and fatigue as well as improvement in performance status.

The CR rate by disease type was $63 \%$ for BJP type, $26 \%$ for IgA type, and $20 \%$ for IgG type. Given that the BJP and IgA type diseases are known to respond better to IFN- $\alpha$ than IgG type, the difference in the response rate among disease types may be attributable to IFN- $\alpha$.

As with VAD therapy, the DMVM+IFN- $\alpha$ regimen includes high-dose dexamethasone. Among the reports on VAD therapy to date, the report by Alexanian showed that the original VAD therapy produced a response rate of $42 \%$, with no indication of $\mathrm{CR}$ rate, and a median survival time of 36 months. VAD therapy provides rapid therapeutic effects, but is associated with early recurrence. Alexanian attributed the main effect of VAD to dexamethasone. The present authors suppose that the effect of dexamethasone persists only for a short duration and cannot be prolonged by other agents included in the VAD therapy (continuous infusion of doxorubicin and vincristine). Nevertheless, the a modified VAD regimen (dexamethasone not administered on days 9 to 12 and 17 to 20) achieved $\mathrm{CR}^{9,10}$, which may have been made possible by early commencement of the next cycle of chemotherapy and increase in dose intensity.

A regimen involving the same combination of drugs as 
Table 5. Effect of DMVM+IFN- $a$ on renal dysfunction for stage B patients

\begin{tabular}{|c|c|c|c|c|c|c|c|c|c|c|c|c|c|}
\hline \multirow[b]{2}{*}{ Patient } & \multirow[b]{2}{*}{ Stage } & \multirow[b]{2}{*}{$\begin{array}{c}\text { Disease } \\
\text { type }\end{array}$} & \multirow[b]{2}{*}{$\begin{array}{l}\text { BJP } \\
\text { (g/day) }\end{array}$} & \multicolumn{6}{|c|}{ Dose $(\%)$} & \multicolumn{4}{|c|}{ Creatinine $(\mathrm{mg} / \mathrm{dl})$} \\
\hline & & & & Dex & MCNU & Vcr & Mel & IFN- $a$ & & $\begin{array}{l}\text { Before } \\
\text { treatment }\end{array}$ & Nadir & $\begin{array}{r}\text { After } 1 \\
\text { course }\end{array}$ & Effect \\
\hline HS & IIIB & $\mathrm{BJP} \lambda$ & $\mathrm{ND}$ & 100 & 100 & 100 & 100 & Daily & & 3.6 & 1.1 & 1.3 & $\mathrm{CR}$ \\
\hline SM & IIIB & $\mathrm{BJP} x$ & 21.8 & 100 & 100 & 100 & 100 & Daily & & 3.3 & 1.4 & 1.5 & $\mathrm{CR}$ \\
\hline FT & IIB & $\operatorname{IgG} \lambda$ & \pm & 50 & 100 & 100 & 100 & Daily & & 3.3 & 1.2 & 1.2 & $\mathrm{CR}$ \\
\hline FM & IIIB & $\mathrm{BJP} x$ & 3.8 & 100 & 100 & 88 & 100 & Dairy & & 2.9 & 2.8 & 2.8 & $\mathrm{CR}$ \\
\hline AN & IIIB & $\mathrm{BJP} x$ & ND & 100 & 100 & 100 & 100 & Dairy & & 3.3 & 1.3 & 0.7 & $\mathrm{CR}$ \\
\hline SS & IIB & $\operatorname{Ig} A \lambda$ & 0.2 & 100 & 71 & 56 & 33 & Every other day & & 2.2 & 1.8 & 2.4 & $\mathrm{CR}$ \\
\hline $\mathrm{OH}$ & IIA & $\mathrm{BJP} x$ & 3.1 & $50^{*}$ & 71 & 100 & 50 & Daily & & 1.9 & 1.3 & 1.3 & $\mathrm{CR}$ \\
\hline YY & IIIA & $\operatorname{Ig} A \lambda$ & + & 100 & 100 & 100 & 100 & Daily & & 1.8 & 0.7 & 0.8 & $\mathrm{CR}$ \\
\hline HK & IIA $^{*}$ & $\operatorname{IgG} \lambda$ & 6.0 & 100 & 100 & 100 & 100 & Daily & & 1.6 & 1.0 & 1.0 & $\mathrm{CR}$ \\
\hline $\mathrm{TN}$ & IIIA & $\operatorname{IgG} x$ & ND & 33 & 100 & 100 & 100 & Daily & & 1.5 & 0.7 & 0.7 & $\mathrm{CR}$ \\
\hline MT & IIIA & $\operatorname{IgG} \lambda$ & ND & 80 & 71 & 100 & 100 & Every other day & & 1.2 & 0.9 & 0.9 & $\mathrm{CR}$ \\
\hline $\mathrm{SF}$ & IIIB & $\mathrm{BJP} x$ & 12.5 & 100 & 100 & 100 & 100 & 0 & & 3.3 & 1.5 & 2.3 & PR \\
\hline MH & IIIB & $\mathrm{IgG} \varkappa$ & ND & 100 & 71 & 56 & 67 & Daily & & 3.0 & 2.4 & 2.4 & PR \\
\hline MS & IIIB & $\mathrm{BJP} \lambda$ & 1.8 & 75 & 71 & 100 & 33 & Every other day & & 2.4 & 1.9 & 1.9 & PR \\
\hline MH & IIIB & $\operatorname{Ig} A x$ & 2.3 & 100 & 100 & 100 & 100 & Daily & & 2.3 & 0.9 & 0.9 & PR \\
\hline NY & IIIB & $\mathrm{IgG} \varkappa$ & 0.3 & 100 & 71 & 56 & 100 & $0 \#$ & & 2.1 & 0.9 & 1.1 & PR \\
\hline MK & IIIA & $\operatorname{IgG} \lambda$ & - & 100 & 100 & 100 & 100 & Daily & & 1.9 & 1.3 & 1.3 & PR \\
\hline YS & IIIA $^{*}$ & $\operatorname{IgG} x$ & 0.5 & 100 & 100 & 100 & 100 & Daily & & 1.5 & 1.0 & 1.0 & PR \\
\hline \multirow[t]{2}{*}{ ST } & IIIA & $\operatorname{Ig} A \lambda$ & 0 & 100 & 100 & 100 & 100 & Daily & & 1.3 & 1.1 & 1.1 & PR \\
\hline & & & & & & & & & Mean & 2.3 & 1.3 & 1.4 & \\
\hline
\end{tabular}

Detailed data were not obtained for three patients. * Dose reduction due to diabetes mellitus. Therapy discontinued due to steroid myopathy. \# IFN- $a$ not used because of outpatient status. Eight patients with mild renal dysfunction (creatinine between 1.2 and 2.0) were included.

ours is the ROAD-IN therapy reported by Wada, et $a l^{11}$. The ROAD-IN regimen has the same combination of drugs as the DMVM+IFN- $\alpha$ regimen, but differs in that the IFN- $\alpha$ therapy is administered sequentially after for 3 weeks following the DMVM therapy for the next 3 weeks. This regimen achieved a response rate of $75 \%$ (CR rate of $24 \%$ ) and a median survival time of 3.6 years, comparable to our results. Prospective randomized study should would be required in order to clarify the optimal timing of IFN- $\alpha$ treatment.

Our regimen produced a high response rate for untreated patients. Table 7 shows representative studies of chemotherapy and hematopoietic stem cell transplantation (BMT and PBSCT) that achieved high response rates ${ }^{1-18}$. Despite wideranging treatment modalities, $\mathrm{CR}$ rates fall within the range of 22 to $30 \%$, except for the study by Aviles. Although The results of our study are not inconsistent with these reports ${ }^{9-11}$, they and are superior to the others in regards to untreated patients (CR rate of $37 \%$ ).

A recent breakthrough in massive chemotherapy involving hematopoietic stem cell transplantation, which promises to produce a high $\mathrm{CR}$ rate and longer survival time compared to chemotherapy, includes tandem transplantation involving two cycles of auto-PBSCT in a short period ${ }^{16,17}$. However, transplantation is difficult to apply to the elderly ( $\geq 65$ years old) or patients with organ disorders. In contrast, as chemotherapy is widely applicable, the DMVM-IFN- $\alpha$ therapy can be a choice for patients in any condition (old age or renal dysfunction).

Myeloma Trialists' Collaborative Group (MTCG) reported in 1998 that as a result of the meta-analysis of MP therapy versus combination chemotherapy (CCT), combina- 
Table 6. Adverse reactions and abnormal laboratory findings

\begin{tabular}{|c|c|c|c|}
\hline Number of adverse reactions & $34 / 140(24.3 \%)$ & & \\
\hline Number of and abnormal laboratory findings & $76 / 140(54.3 \%)$ & & \\
\hline \multicolumn{2}{|l|}{ Subjective or objective adverse reactions } & Number of patients & Frequency $(\%)$ \\
\hline \multicolumn{2}{|l|}{ Malaise } & 6 & 4.3 \\
\hline \multicolumn{2}{|l|}{ Headache } & 1 & 0.7 \\
\hline \multicolumn{2}{|l|}{ Delusion/unrest } & 1 & 0.7 \\
\hline \multicolumn{2}{|l|}{ Nausea/vomiting } & 2 & 1.4 \\
\hline \multicolumn{2}{|l|}{ Anorexia } & 1 & 0.7 \\
\hline \multicolumn{2}{|l|}{ Diarrhea } & 1 & 0.7 \\
\hline \multicolumn{2}{|c|}{ Ocular gandus hemorrhage (visual impairement), Abnormal ophthalmoscopic findings } & 2 & 1.4 \\
\hline \multicolumn{2}{|l|}{ Depilation } & 2 & 1.4 \\
\hline \multicolumn{2}{|l|}{ Interstitial pneumonia } & 1 & 0.7 \\
\hline \multicolumn{2}{|l|}{ Generalized erythroderma } & 1 & 0.7 \\
\hline \multicolumn{2}{|l|}{ Sudden deafness } & 1 & 0.7 \\
\hline \multicolumn{2}{|l|}{ Right scapulalgia } & 1 & 0.7 \\
\hline \multicolumn{4}{|l|}{ Abnormal laboratory findings } \\
\hline \multicolumn{2}{|l|}{ Leukocytopenia } & 17 & 12.1 \\
\hline
\end{tabular}

tion chemotherapy improved response rates over MP but did not contribute to survival ${ }^{19}$. We suggest that not only the good remission status but also optimal maintenance treatment is required for the improvement of survival times.

Despite progress in therapy for MM, approximately $20 \%$ of patients are refractory to therapy. A cure for MM is hardly anticipated because survival curves have not reached plateaus in these studies. Following up prognosis of patients showing CR in these studies will disclose the probability of cure for MM.

In recent years, evidence has been accumulated for genetically unstable MM following a multi-step transformation process $^{20}$. In addition, several mechanisms of drug resistance in MM have been clarified ${ }^{21}$. It should be noted that MM is extremely susceptible to treatment resistance is very likely to develop in MM, thereby readily progressing to advanced stages. The current challenge in therapy for MM is in finding the way from $\mathrm{CR}$ to cure.

\section{ACKNOWLEDGMENTS}

We thank K. Nukui, H. Arano, and K. Hosokawa for their skillful assistance in statistical analysis.

\section{REFERENCES}

1 Barlogie B : Biology and therapy of multiple myeloma in 1996. Semin Hematol 34 (Suppl 1) : 67-72, 1997

2 Kitani T: New protocols for myeloma chemotherapy plus IFN- $\alpha$. Jap J Clin Hematol 34 : 455-459, 1993

3 Barlogie B, Smith L, Alexanian R: Effective treatment of advanced multiple myeloma refractory to alkylating agents. $\mathrm{N}$ Engl $\mathrm{J}$ Med : 310, 1984

4 Alexanian R, Barlogie B, Tucker S: VAD-based regimens as primary treatment for multiple myeloma. Am J Haematol 33 : 86- 89, 1990 
Table 7. Comparison of therapeutic results that included CR

\begin{tabular}{|c|c|c|c|c|c|c|c|c|c|c|c|}
\hline \multirow{2}{*}{$\begin{array}{l}\text { Treatment } \\
\text { (reported by, year of } \\
\text { latest report) }\end{array}$} & \multicolumn{2}{|c|}{ Effects $(\%)$} & \multicolumn{4}{|c|}{$\begin{array}{l}50 \% \text { remission period } \\
\text { (months) }\end{array}$} & \multicolumn{3}{|c|}{$\begin{array}{l}50 \% \text { survival period } \\
\text { (months) }\end{array}$} & \multicolumn{2}{|c|}{ Survival period } \\
\hline & $\mathrm{CR}+\mathrm{PR}$ & $\mathrm{CR}$ & $\mathrm{CR}+\mathrm{PR}$ & $\mathrm{CR}$ & PR & All patients & $\mathrm{CR}+\mathrm{PR}$ & $\mathrm{CR}$ & PR & All patients & $\mathrm{CR}$ \\
\hline $\begin{array}{l}\text { MP } \\
\text { (Gregory 1992) }\end{array}$ & $50-60$ & Rare & & & & $\begin{array}{c}19-50 \\
\text { (mean 32.4) }\end{array}$ & & & & $\begin{array}{c}2 \text { years } \\
58 \%\end{array}$ & \\
\hline $\begin{array}{l}\text { Modified VAD } \\
\quad \text { (Samson 1989) }\end{array}$ & 84 & 28 & 18 & $18^{*}$ & $18^{*}$ & 44 & NM & NM & NM & $\begin{array}{c}2 \text { years } \\
75 \%\end{array}$ & $\begin{array}{c}2 \text { years } \\
90 \%\end{array}$ \\
\hline $\begin{array}{l}\text { Modified VAD } \\
\text { (Anderson 1995) }\end{array}$ & 84 & 27 & NM & $\mathrm{NM}$ & NM & & 36 & NM & 28 & months & \\
\hline $\begin{array}{l}\text { High-dose melphalan therapy } \\
\text { (Cunningham 1994) }\end{array}$ & 82 & 32 & 18 & $\mathrm{NM}^{*}$ & $\mathrm{NM}^{*}$ & 47 & NM & NM & NM & $\begin{array}{l}9 \text { years } \\
34.5 \%\end{array}$ & \\
\hline $\begin{array}{l}\text { VBMCP+IFN- } a \\
(\text { Oken 1996) }\end{array}$ & 80 & 30 & 35 & 46 & NM & 42 & NM & NM & NM & $\begin{array}{c}5 \text { years } \\
42 \%\end{array}$ & $\begin{array}{l}4 \text { years } \\
82 \%\end{array}$ \\
\hline $\begin{array}{l}\text { CVMP/ CVNP/ BEVD+IFN- } a \\
\quad(\text { Aviles 1995) }\end{array}$ & $\begin{array}{c}80 \\
(\text { no PR) }\end{array}$ & 80 & 32 & 32 & - & \# & $\#$ & \# & - & $\begin{array}{c}5 \text { years } \\
72 \%\end{array}$ & \\
\hline $\begin{array}{l}\text { ROAD- IN } \\
\qquad(\text { Wada2000) }\end{array}$ & 75 & 24 & NM & NM & NM & 3.6 (years) & 4.3 (years) & NM & NM & $\begin{array}{l}7 \text { years } \\
26 \%\end{array}$ & \\
\hline $\begin{array}{l}\text { DMVM+IFN- } a \\
\quad(\text { Kitani 2004) }\end{array}$ & 76 & 27 & 15.1 & $21.2^{*}$ & $11.0^{*}$ & 38.1 & 45.8 & $46.9^{*}$ & $39.7^{*}$ & $\begin{array}{c}5 \text { years } \\
34 \%\end{array}$ & \\
\hline $\begin{array}{l}\text { atuo-BMT } \\
\quad \text { (Ataal 1996) }\end{array}$ & 81 & 22 & 27 & NM & NM & \# & NM & NM & NM & $\begin{array}{l}5 \text { years } \\
52 \%\end{array}$ & \\
\hline $\begin{array}{l}\text { Tandem autologous transplantation } \\
\text { (Barlogie 1997) }\end{array}$ & 85 & 40 & 49 & NM & NM & $62+$ & NM & NM & NM & & \\
\hline $\begin{array}{l}\text { Tandem autologous transplantation } \\
\text { (Attal 2003) }\end{array}$ & 88 & 50 & 36 & NM & $\mathrm{NM}$ & 58 & NM & NM & $\mathrm{NM}$ & $\begin{array}{c}7 \text { years } \\
42 \%\end{array}$ & \\
\hline allo-SCT ( Gahrton 2001) & & & & & & & & & & 3 years & \\
\hline 1983-1994 : BMT & NM & 54 & NM & NM & NM & 10 & NM & NM & NM & $35 \%$ & \\
\hline 1994-1998： BMT & & 53 & & & & 50 & & & & $55 \%$ & \\
\hline 1994- 1998: PBSCT & & 50 & & & & a & & & & $57 \%$ & \\
\hline
\end{tabular}

These results were for previously untreated patients, except for allo-BMT (Gahrton) and our study. The survival period in patients who received transplantation was calculated from the beginning of transplantation by Gahrton et al. and from the beginning of the induction therapy before transplantation by Attal et al. NM : Not mentioned. \# Survival rate ${ }^{3} 50 \%$ at the time of investigation. ${ }^{19} *$ No significant difference between CR and PR.

5 Alexanian R, Dimopourous MA, Delasalle K, Barlogie B : Primary dexamethasone treatment of multiple myeloma. Blood 80 : 887- 890, 1992

6 Cooper MR, Welander CE : Interferon in the treatment of multiple myeloma. Cancer 59: 594-600, 1987

7 Alexanian R, Haut A, Khan AU, Lane M, McKelvey EM, Migliore PJ, Stuckey WJ Jr, Wilson HE: Treatment for multiple myeloma. Combination chemotherapy with different melphalan dose regimens. JAMA 208: 1680-1685, 1969

8 Gregory WM, Richards MA, Malpas JS : Combination chemotherapy versus melphalan and prednisolone in the treatment of multiple myeloma : An overview of published trials. J Clin Oncol 10 : 334-342, 1992

9 Samson D, Gaminara E, Newland A, Van de Pette J, Kearney J, McCarthy D, Joyner M, Aston L, Mitchell T, Hamon M, et al. : Infusion of vincristine and doxorubicin with oral dexamethasone at first line therapy for multiple myeloma. Lancet 2: 882-885, 1989

10 Arderson H, Scarffe JH, Ranson M, Young R, Wieringa GS,
Morgenstern GR, Fitzsimmons L, Ryder D : VAD therapy as remission induction for multiple myeloma. Brit J Cancer 71 : 326-330, 1995

11 Wada M, Mizoguchi H, Kuriya SI, Taguchi H, Kawamura T, Maekawa I, Shimazaki C, Sato Y, Niho Y, Miyazaki T, Shibata A, Kitani T, Hamajima N, Ohno R : Induction therapy consisting of alternating cycles of ranimustine, vincristine, melphalan, dexamethasone and interferon alpha (ROAD-IN) and a randomized comparison of interferon alpha maintenance in multiple myeloma : a co-operative study in Japan. Br J Haematol 109 : 805- 814, 2000

12 Cunningham D, Paz-Ares L, Gore ME, Malpas J, Hickish T, Nicolson M, Meldrum M, Viner C, Milan S, Selby PJ, et al. : High-dose melphalan for multiple myeloma: Long-term follow up data. J Clin Oncol 12: 764-768, 1994

13 Oken MM : Complete remission induction with combined VBMCP chemotherapy and interferon (rIFN $\alpha 2 b$ ) in patients with multiple myeloma. Leuk Lymphoma 20 : 447-452, 1996

14 Aviles A: Alternating combination chemotherapy and interferon improves survival in poor prognosis multiple myeloma. Clin 
Oncol 7: 97-101, 1995

15 Attal M : A prospective randomized trial of autologous bone marrow transplantation and chemotherapy in multiple myeloma. $\mathrm{N}$ Engl J Med 335 : 91-97, 1996

16 Barlogie B, Jagannath S, Vesole DH, Naucke S, Cheson B, Mattox S, Bracy D, Salmon S, Jacobson J, Crowley J, Tricot G : Superiority of tandem autologous transplantation over standard therapy for previously untreated multiple myeloma. Blood 89 : 789-793, 1997

17 Attal M, Harousseau JL, Facon T, Guilhot F, Doyen C, Fuzibet JG, Monconduit M, Hulin C, Caillot D, Bouabdallah R, Voillat L, Sotto JJ, Grosbois B, Bataille R; InterGroupe Francophone du Myelome. : Single versus double autologous stem-cell transplantation for multiple myeloma. N Engl J Med 349 : 2495-2502, 2003

18 Gahrton G, Svensson H, Cavo M, Apperly J, Bacigalupo A, Bjorkstrand B, Blade J, Cornelissen J, de Laurenzi A, Facon T, Ljung- man P, Michallet M, Niederwieser D, Powles R, Reiffers J, Russell NH, Samson D, Schaefer UW, Schattenberg A, Tura S, Verdonck LF, Vernant JP, Willemze R, Volin L; European Group for Blood and Marrow Transplantation. : Progress in allogenic bone marrow and peripheral blood stem cell transplantation for multiple myeloma : a comparison between transplants performed 1983-93 and 1994-8 at European Group for Blood and Marrow Transplantation centres. Brit J Haematol 113 : 209-216, 2001

19 Myeloma Trialists' Collaborative Group: Combination chemotherapy versus melphalan plus prednisone as treatment for multiple myeloma: an overview of 6,633 patients from 27 randomized trials. J Clin Oncol 16: 3832-3842, 1998

20 Hallek M, Bergsagel PL, Anderson KC : Multiple myeloma : Increasing evidence for a multistep transformation process. Blood 91: 3-21, 1998

21 Sonneveld P, Lokhorst HM, Vossebeld P : Drug resistance in multiple myeloma Semin Hematol 34 : 34-39, 1997 